\title{
Qualitative analysis of AWJ factors affecting the surface roughness
}

\author{
Sergej Hloch, Stanislav Fabian
}

\begin{abstract}
The paper deals with experimental research and evaluation of abrasive waterjet cutting technology process by evaluation of technological factors, which influence the microgeometry (average roughness) of $10 \mathrm{~mm}$ thick stainless steel tooled workpiece surface through design of experiments. Significance of six chosen process factors - independent variables (traverse rate, abrasive mass flow rate, pressure, $\mathrm{J} / \mathrm{T}$ abbreviation and feeding direction that influence the surface quality has been evaluated by factors experiment type $2^{6}$. The surface quality has been evaluated by static quality characteristic average roughness $\mathrm{Ra}$. The multiple nonlinear regression equation obtained from ANOVA gives the level quality Ra as a function of the treatment factors. Different factor significance has been found, which generated surface profile under defined conditions by abrasive waterjet. The regression equations obtained from ANOVA and multiple linear regressions give the level quality $\mathrm{Ra}$ as a function of the treatment factors.
\end{abstract}

\section{Introduction}

Design of Experiments is a standard statistical technique used in quality engineering, manufacturing, and other industries to identify significant or sensitive factors (independent variables) and levels their factor values that influence system performance and variability. This technique is especially useful when there is the need to understand the interactions and effects of several system variables and an absence of concrete information. Manufacturing engineers can use experimental designs to establish a cost-effective set of experiments to identify factors and levels that have the most and least impact on system performance. In current European conditions raising emphasis is posed to manufacturing processes quality with minimal environmental impact, connected with lower energetic and material consumption. Competition and scientific progress requires introduction of technologies that perform challenging claims of modern production in automation field, from economy, environmental and energy efficiency point of view. Abrasive waterjet cutting represents all of these claims.

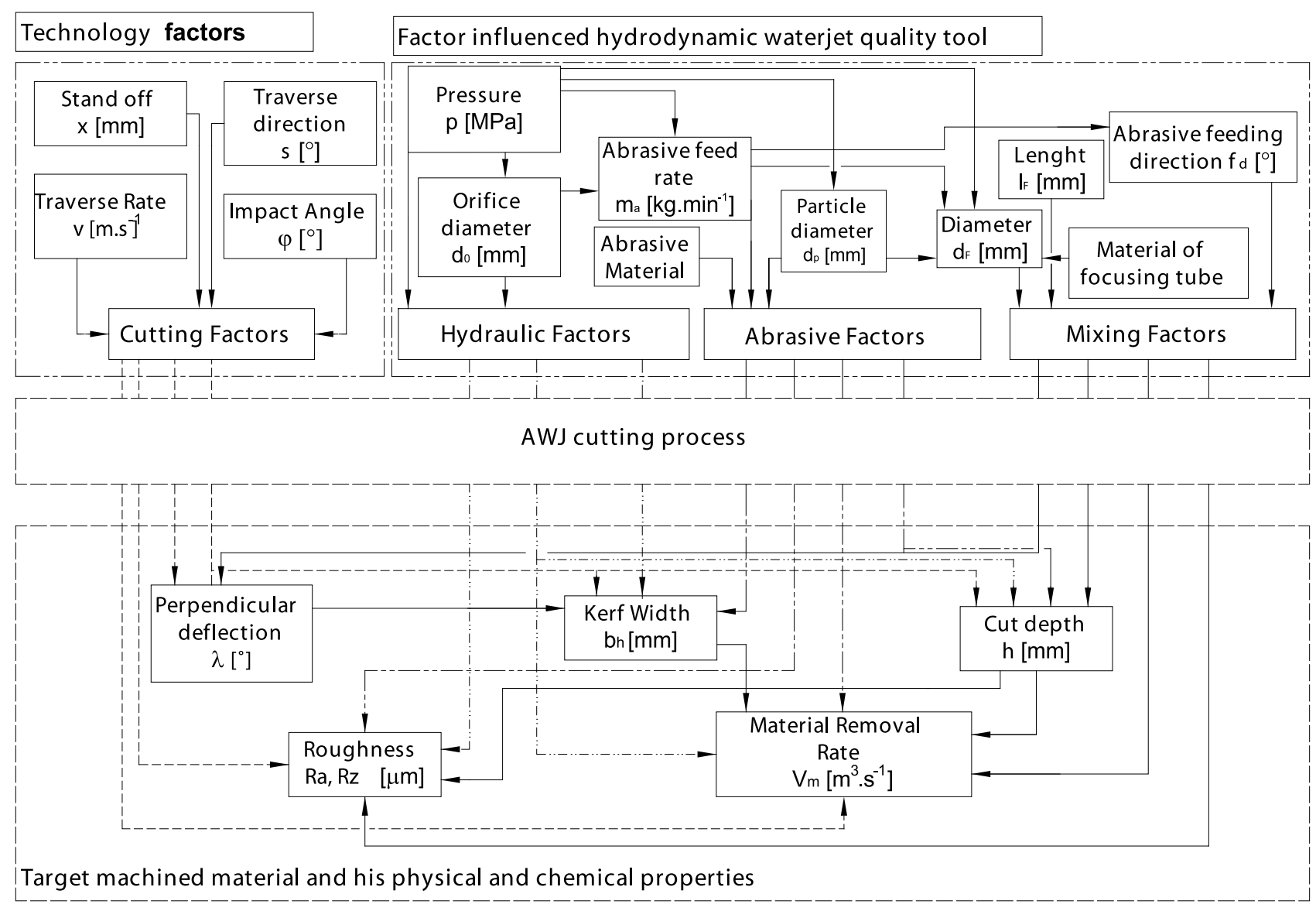

Fig. 1. AWJ cutting process model; factors vs. parameters 


\section{Related and previous works}

Abrasive waterjet machining belongs among complicated dynamical and stochastic processes with incomplete information about mechanism and side effects character. Their complicated appearance in large amount and parameters multiform determining process behaviour in large number of relations among parameters, and their interactions. [15] Their complicacy incomplete knowledge functioning mechanisms and large amount of factors entering to the process complicate of mathematical model fitting by theoretical and analytical methods [12,16]. Vice versa a mathematic-statistical method allows fitting of statistical models even from relative large amount input data. The nature of the mechanisms involved in the domain of AWJ machining is still not well understood but is essential for AWJ control improvement. In spite of great research effort and good knowledge in the field of progressive technologies there are number unexplained facts. One of them is influence of process factors on workpiece surface quality. $[6,10]$ The work presented in that study investigates a micro-geometrical aspect of the cutting quality of the average roughness. It is necessary to ensure asked quality characteristic of the cutting surface, which conditional to knowledge of the process function dependency between product quality parameters and abrasive waterjet manufacturing system factors [9]. Most scientific papers concerning to the evaluation of microgeometrical features of abrasive waterjet cutting are available $[1,2,3,4,7,11]$. The object is to determine the final shape of the surface quality, which is a function of the geometric characteristics of the abrasive waterjet tool and its awj factors that are divided into two basic groups (fig.2); direct and indirect. Factors of indirect group influenced quality of the created tool where hydro-dynamic factors, mixing factors and abrasive factors belong. These factors influence the qualitative characteristics of the tool, the speed, diameter kinetic energy of the stream. Generated tool through these factors enters to the cutting technology process at material at the large number locality, by means of direct factors. There belongs traverse rate; stand off distance, impact angle and number of passes. Through cutting factors, created tool hits the workpiece the at upper erosion base (fig.1), where erosion process begins $[11,13]$.

In order to investigate the influence of abrasive waterjet process factors on average roughness Ra cutting quality, full factorial design for four independent variables has been designed. Full factorial analysis was used to obtain the combination of values that can optimize the response within the region of the four dimensional observation spaces, which allows one to design a minimal number of experimental runs. Among the many process variables that influence the cutting results, four have been selected and considered as factors in the experimental phase. The variable of each constituent at levels: -1 , and +1 is given in Table 1.

The experimental cuts have been performed in a random sequence, in order to reduce the effect of any possible error. A $2^{6}$ full factorial analysis has been used with 3 replicates at the center point, leading the total number of 64 experiments. Considering that the four levels of the $\mathrm{x}_{1}, \mathrm{x}_{2}$,

\begin{tabular}{|l|l|l|c|c|}
\hline \multirow{2}{*}{$\mathrm{N}$} & \multicolumn{2}{l|}{ Factors } & \multicolumn{2}{l|}{ Factor level } \\
\cline { 2 - 5 } & Var. & Terminology and dimension & -1 & +1 \\
\hline 1 & $\mathrm{x}_{1}$ & J/T abbreviation [mm] & $0,1 / 1$ & $0,14 / 1,2$ \\
\hline 2 & $\mathrm{x}_{2}$ & Abrasive mass flow rate $\left[\mathrm{g} \cdot \mathrm{min}^{-1}\right]$ & 300 & 500 \\
\hline 3 & $\mathrm{x}_{3}$ & Pressure [MPa] & 200 & 350 \\
\hline 4 & $\mathrm{x}_{4}$ & Traverse rate [mm. $\left.\mathrm{min}^{-1}\right]$ & 70 & 120 \\
\hline 5 & $\mathrm{x}_{5}$ & Depth [mm] & 1 & 9 \\
\hline 6 & $\mathrm{x}_{6}$ & Traverse direction & -180 & 180 \\
\hline
\end{tabular}

Table 1. Coded independent variables at defined levels

$\mathrm{X}_{3}, \mathrm{X}_{4}, \mathrm{X}_{5}, \mathrm{x}_{6}$ and variables are -1 and 1 , the designed matrix is 64-obsevations for dependent variable Ra. The graphical interpretations of factorial design is illustrated in the figure (2) Specimens series A has been made with indenpendent variable - factor J/T at high level 0,14/1,2 (+1) and specimens series $B$ with lowest level of $\mathrm{J} / \mathrm{T}$ abbreviation. The behaviour of the present system can describe the nonlinear polynomial exponential equation (1), which includes all interaction terms regardless of their significance:

$y=b_{0} x_{0}+b_{1} x_{1}+b_{2} x_{2}+b_{3} x_{3}+b_{4} x_{4}+b_{5} x_{5}+b_{6} x_{6} \ldots+b_{123456} x_{1} x_{2} x_{3} x_{4} x_{5} x_{6}$
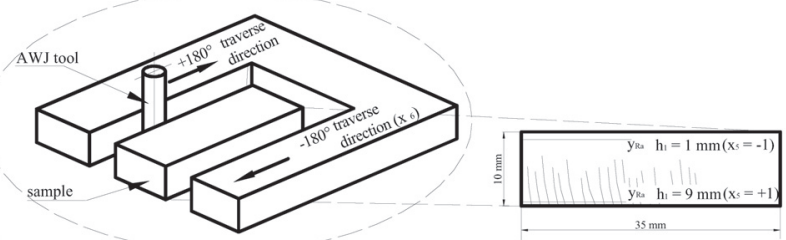

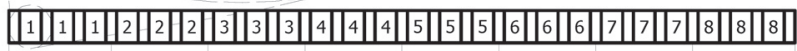

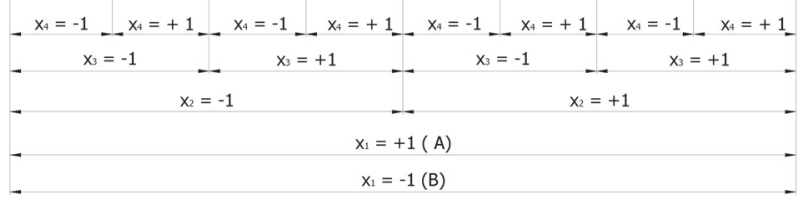

Fig.2. Experimental methodology graphic illustration of specimens' series $A$ and $B$

For investigation of the influence of the traverse rate the samples created for this purpose have been cut in two directions $+180^{\circ}$ and $-180^{\circ}$ (fig. 4 ). Traverse direction has been added to the experiment to explain the significance with connection of the selected factors.

\subsection{Experimental set up}

A two dimensional abrasive waterjet machine Wating, was used in this work with following specification: work table $\mathrm{x}$-axis $2000 \mathrm{~mm}$, y-axis $3000 \mathrm{~mm}$, z-axis discrete motion, with maximum traverse rate of $250 \mathrm{~mm}$. $\mathrm{min}^{-1}$. The highpressure intensifier pump was used the Ingersoll-Rand Streamline model with maximum pressure $380 \mathrm{MPa}$. As a cutting an Autoline cutting head from Ingersoll-Rand head has been used. The mechanical properties and chemical composition of the workpiece with austenitic composition is shown in table 2. The properties of each sample are: length $35 \mathrm{~mm}$, width $8 \mathrm{~mm}$, and height $10 \mathrm{~mm}$. Abrasive machining conditions used in this study are listed in the table 2. The abrasive used in this experiment is Barton garnet, mesh 80 , which is widely used for abrasive waterjet machining. 
The stainless steel has been chosen as a target material upon these grounds: material is very attractive, because of its resistance to corrosion; it can provide significant value creation for the end user when considering all of the important attributes and how they help to bring reliability, performance, and safety to industry and the consumer. Fig. 4 shows the samples made according DoE (tab. 2, fig. 2).

\begin{tabular}{|c|c|c|c|}
\hline Constant factors & Values & Variable factors & Values \\
\hline Standoff & $2 \mathrm{~mm}$ & Pressure $\mathrm{p}[\mathrm{MPa}]$ & $200 / 350$ \\
\hline \multicolumn{2}{|c|}{$\begin{array}{l}\text { Abrasive material Barton } \\
\text { Garnet Mesh } 80\end{array}$} & Traverse rate $v\left[\mathrm{~mm} \cdot \mathrm{min}^{-1}\right]$ & $70 / 120$ \\
\hline \multicolumn{2}{|c|}{ 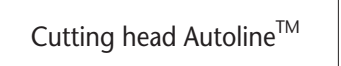 } & $\mathrm{J} / \mathrm{T}$ abbreviation & $\begin{array}{c}0,14 / 1,2 \\
0,1 / 1\end{array}$ \\
\hline Impact angle $\varphi$ & $90^{\circ}$ & $\begin{array}{l}\text { Abrasive mass flow rate } \\
{\left[\mathrm{g} \cdot \mathrm{min}^{-1}\right]}\end{array}$ & $200 / 500$ \\
\hline \multicolumn{2}{|c|}{$\begin{array}{l}\text { Target material: Stainless } \\
\text { steel AISI } 304\end{array}$} & Material thickness $\mathrm{h}[\mathrm{mm}]$ & $1 / 9$ \\
\hline \multicolumn{4}{|c|}{$\begin{array}{l}\text { C max } 0.07 \%, \mathrm{Mn} \max 2.0 \%, \mathrm{P} \max 0.045 \%, \mathrm{~S} \max 0.03 \% \text { Si } \max \\
1 \%, \mathrm{Cr} \text { max } 18 / 20 \%, \mathrm{Ni} 10 \% \\
\text { Tensile Strength Rm } 540 / 680\left[\mathrm{~N} \cdot \mathrm{mm}^{-2}\right] \text {, Slip Limit Rp } 0.2 \% 195 \\
{\left[\mathrm{~N} \cdot \mathrm{mm}^{-2}\right], \mathrm{HRB}=88}\end{array}$} \\
\hline \multicolumn{4}{|c|}{ System characteristics of Streamline pump } \\
\hline Intensifier type & $\begin{array}{c}\text { Double } \\
\text { effect }\end{array}$ & Water pressure (max) & $380 \mathrm{MPa}$ \\
\hline Intensifier power & $50 \mathrm{~kW}$ & Intensification ratio & $20: 1$ \\
\hline Oil pressure (max) & $20 \mathrm{MPa}$ & Accumulator volume & 21 \\
\hline
\end{tabular}

Table 2. Experimental set up

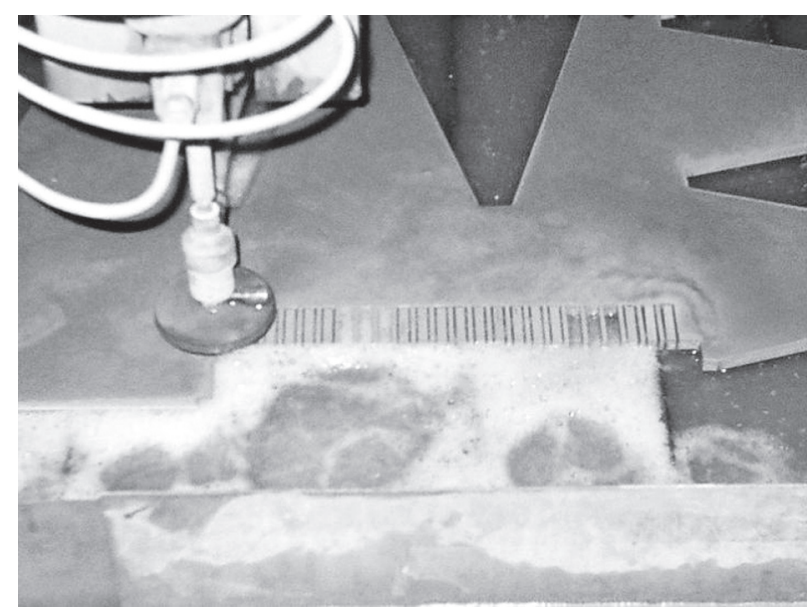

Fig. 3 Production of samples ( $B-$ series $)$

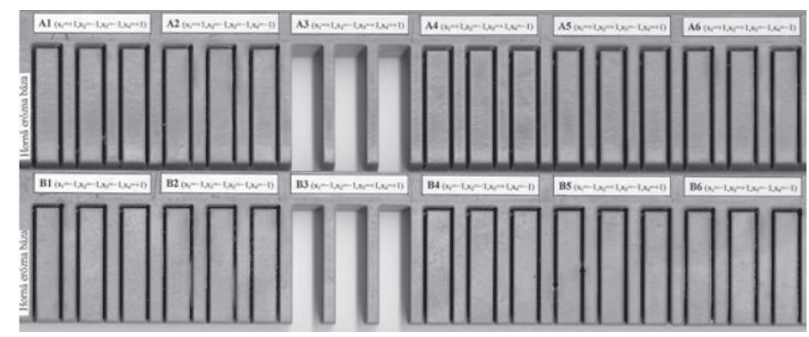

Fig. 4 Example samples of $A$ and $B$ series

\subsection{Measurement procedure}

A digital surftest Mitutoyo 301 has been used to calculate the average roughness with $0.01 \mu \mathrm{m}$ precision of measurement. The measurement procedure consisted of measure variable dependent average roughness $\mathrm{Ra}$ in 1 , and $9 \mathrm{~mm}$ with replicates of 6-times. The measurement dependent variables are shown on figure 4 .

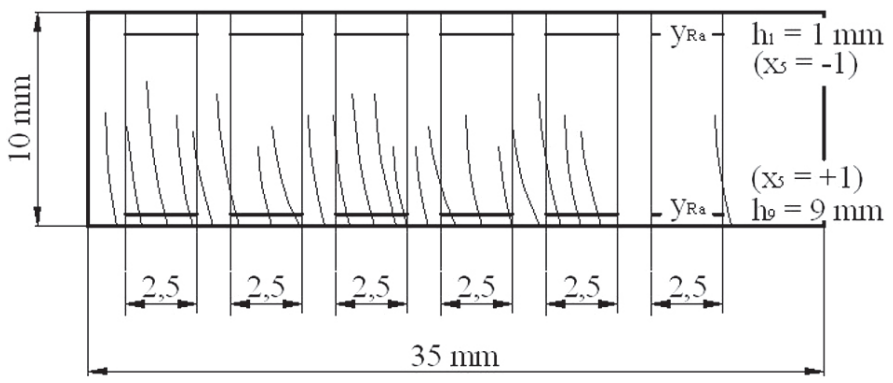

Fig. 5 Measurement procedure
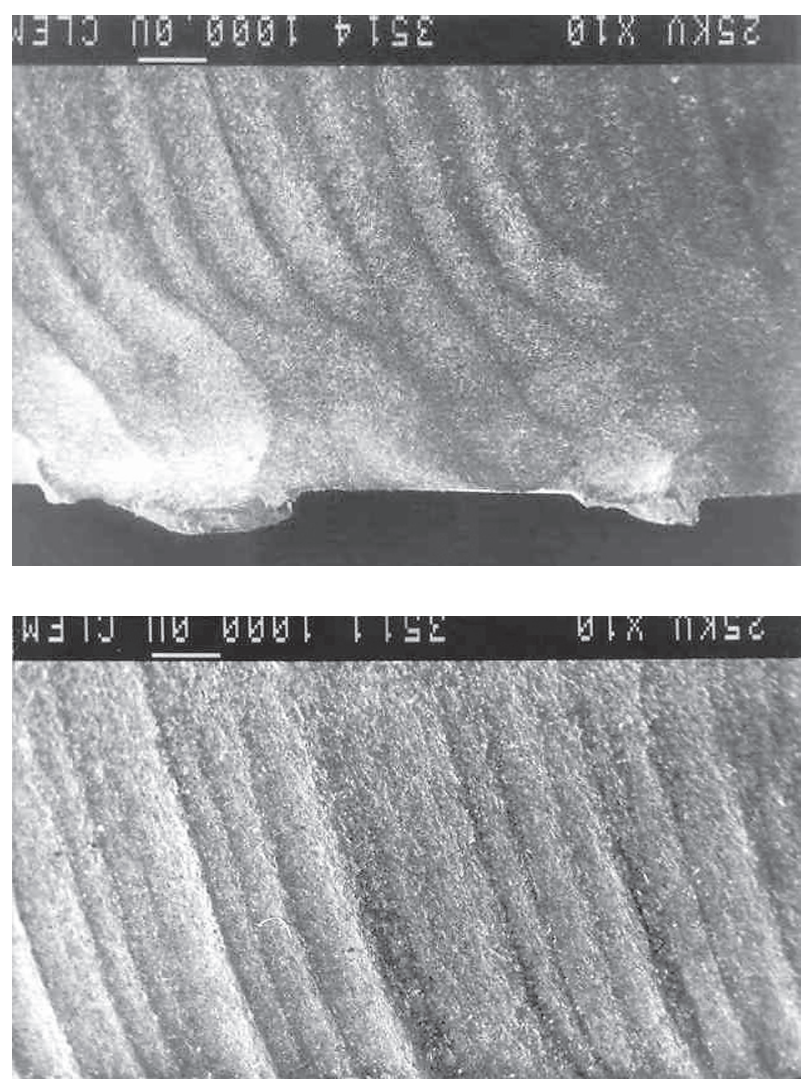

Fig. 6 Example of created workpiece surface by abrasive waterjet

\section{Statistical results}

The quantitative description of the conditions effects on average roughness was performed. Response surface methodology is an empirical modelling technique used to evaluate the relationship between a set of controllable experimental factors and observed results. The results were analyzed using the analysis of variance as appropriate to the experimental design used. The normality of experimental measured data has been tested according Shapiro-Wilkson test criteria for its good power properties as compared to a wide range of alternative tests. Shapiro-Wilkson test proved that 64 values experiments is not greater than critical value $\mathrm{W} \alpha=0.788$ for $\mathrm{n}=6$ and $\alpha=0.05$, respectively value of probability $\mathrm{p}$ is out of range, as preferred significance level $\alpha$, we can accept the null hypothesis about normal distribution measurements repeatability. Figure 5 shows those residual values do not show heteroskedasticity - during of measurement of dependent variable average roughness variance of $\mathrm{Ra}$ 
values has not been observed. Figure 6 shows the normal probability plot of residual values. Computed value obtained reliability for Shapiro-Wikson test of normality $\mathrm{p}=$ 0.020032 and value of $\mathrm{W}$ criteria $\mathrm{W}=0.95114$. According inequality $\mathrm{W}_{\alpha} \geq \mathrm{W}$, we can accept $\mathrm{H}_{0}$ hypothesis about residual values probability.

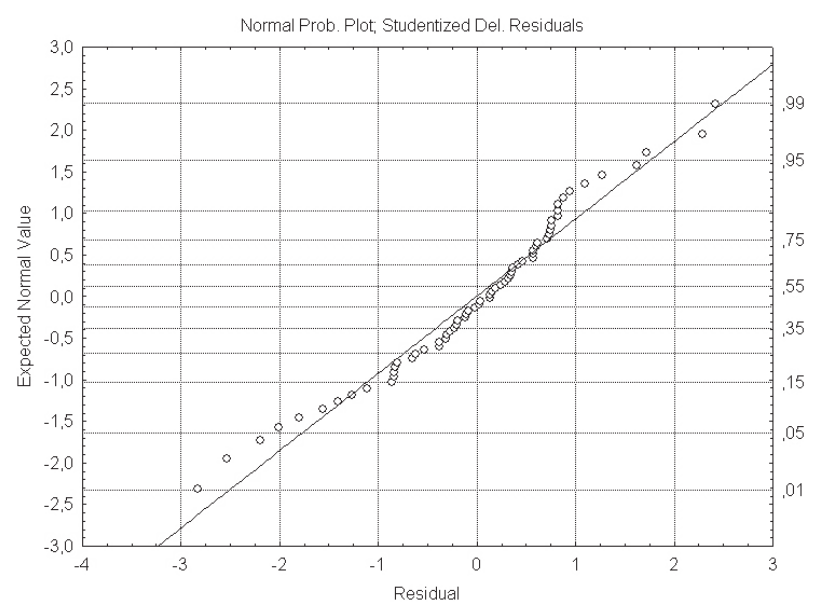

Fig. 7: Normal probability plot

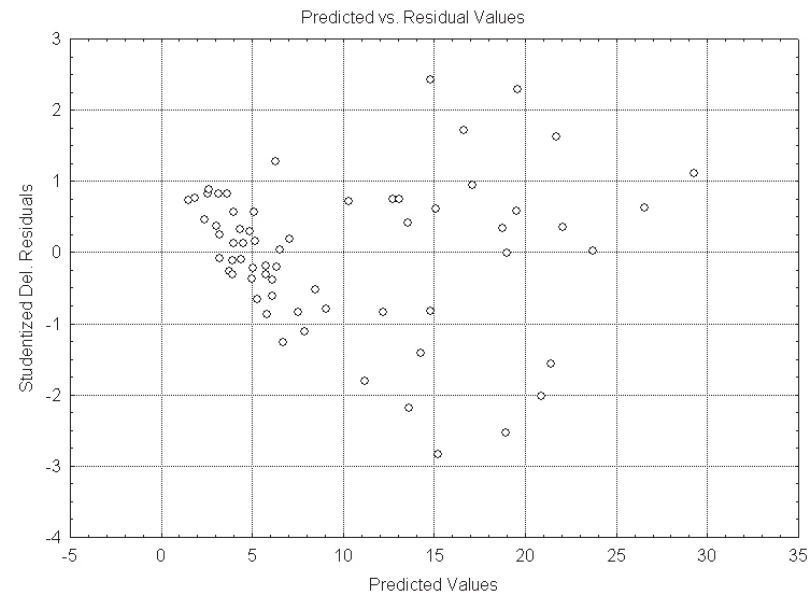

Fig. 8: Predicted vs. residual values

The regression equation obtained after analysis of variance gives the level of average roughness as a function of independent variables: $\mathrm{J} / \mathrm{T}$ abbreviation, abrasive mass flow rate, pressure, traverse speed, traverse direction and material thickness. All terms regard their significance are included in the following equation:

$\hat{\mathrm{R} a}=10,06+1,97 \mathrm{x}_{1}-1,74 \mathrm{x}_{2}-4,35 \mathrm{x}_{3}+4,30 \mathrm{x}_{4}+11,03 \mathrm{x}_{5}-0,013 \mathrm{x}_{6}$

Where: $\mathrm{y}$ is the response, that is average roughness of the surface and $\mathrm{x}_{1}, \mathrm{x}_{2}, \mathrm{x}_{3}, \mathrm{x}_{4}, \mathrm{x}_{5}, \mathrm{x}_{6}$ are coded values of the variables $\mathrm{J} / \mathrm{T}$ abbreviation, abrasive mass flow rate, pressure and traverse rate and the depth. The model has been checked by several criteria. The fit of the model has been expressed by the coefficient of determination $\mathrm{R}^{2}=0,90234$ which was found to be for equation indicating that $90,23 \%$ for the model of the variability in the response can be explained by the models. The value also indicates that only $9,77 \%$ of the total variation is not explained by the model. This shows that equation is suitable model for describing to the response of the average roughness.

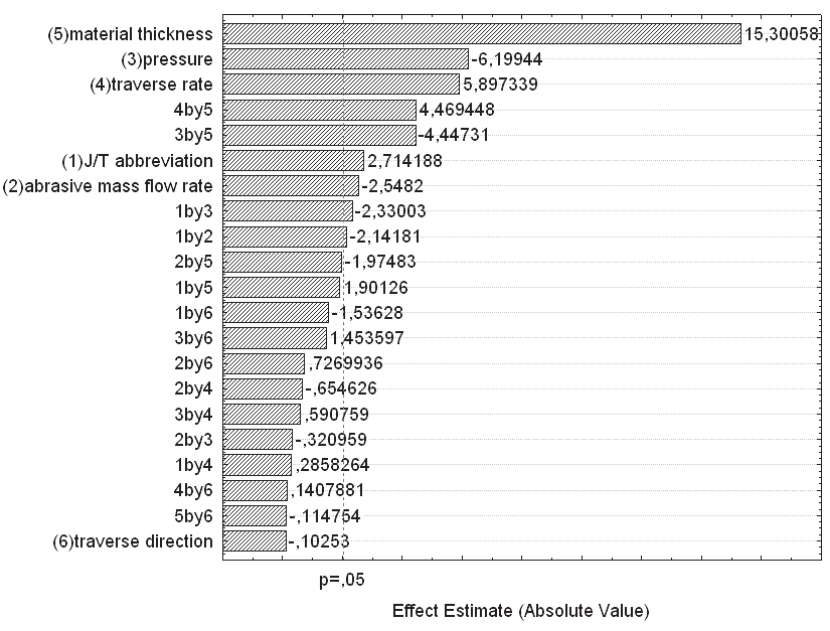

Fig. 9: Pareto charts shows that pressure as a controlable factor was found to be the most sufficient parameter that affects the average roughness

Fig. 9 graphically displays the influence magnitudes of the effects, which are sorted from largest to smallest, from the obtained results. The most important factors affecting the AISI 304 surface quality $\mathrm{x}_{5}$ - material thick, $\mathrm{x}_{3}$ - pressure, $\mathrm{x}_{1}-\mathrm{J} / \mathrm{T}$ abbreviation, $\mathrm{x}_{4}$ - traverse speed and two interactions.

The value of adjusted determination coefficient adj $=0,8535$ is high to advocate for a high significance of the model. The significance of independent variables is interpreted in the Pareto chart of standardized effects for variable Ra (fig. 7). The following figure shows factors significance of treatment factors in \% expression.

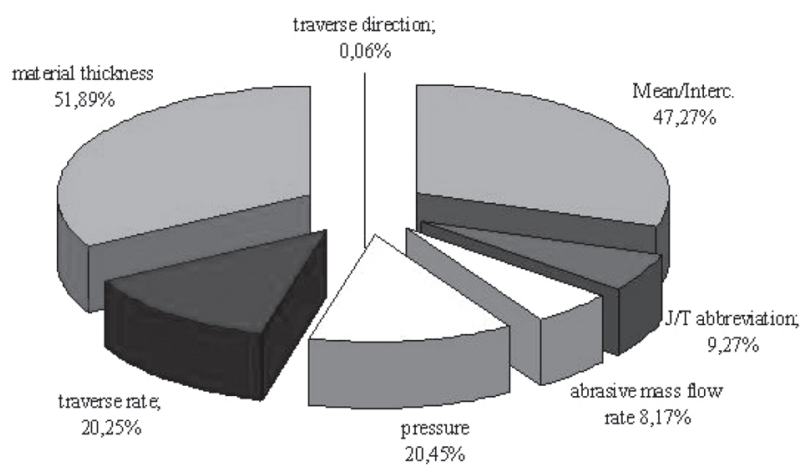

Fig. 10: Factors significance

As can be seen the most important factor is material thickness with significance $51,89 \%$. The second factor affecting the quality of surface roughness of stainless steel is pressure $20,45 \%$, third factor is traverse rate $20,20 \%, \mathrm{~J} / \mathrm{T}$ abbreviation $9,27 \%$ and abrasive mass flow rate $8,17 \%$. Traverse direction in that an experiment is not significant - has no diametric significance on surface quality of average roughness. But significance of that factor increase as the material hardness decrease. It has been observed at the factor designed experiment where the cast aluminium has been used as a target material. As can be seen from the picture 10 the percentual value of absolute value is higher than controllable factors; traverse rate, pressure, abrasive mass flow rate and J/T abbreviation, that indicates that there are associated factors that has a significance influence and has not been included and classified by factor analysis. For 
exact explain of the model fig. 2 a new experiments will be provided. From present state of the art the two factors come in to account abrasive mesh and orifice stand off.

The following figures 11, 12, 13 show fitted surfaces of pressure, rate of speed, $\mathrm{J} / \mathrm{T}$ abbreviation, and abrasive mass flow rate and depth. Three-dimensional surface plots showing predicted microgeometrical quality feature the Ra as a function of independent variable - factors. Figure 10 shows fitted surface of thickness material and traverse direction. Thickness of material is most important factor. $\mathrm{x}_{1}$ factor in not controllable, but it is necessary to know the function in the relationship among the controllable factors. The second significant factor is traverse speed. The darker colour means higher values of surface roughness. The roughness numeric values increases as the traverse rate increase. This observation agrees with the results on stainless steel. With increasing depth average roughness strongly increases that is caused mainly by factors - traverse speed, abrasive mass flow rate and $\mathrm{J} / \mathrm{T}$ abbreviation.

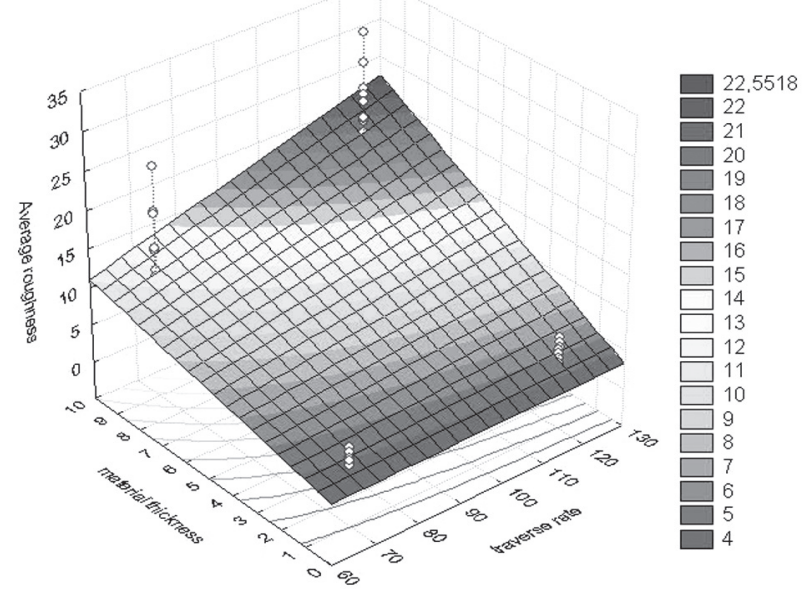

Fig. 11 Fitted surface of material thickness and traverse rate. Threedimensional surface plot showing predicted average roughness as a function of material thickness [mm] and traverse rate [mm. $\left.\mathrm{min}^{-1}\right]$

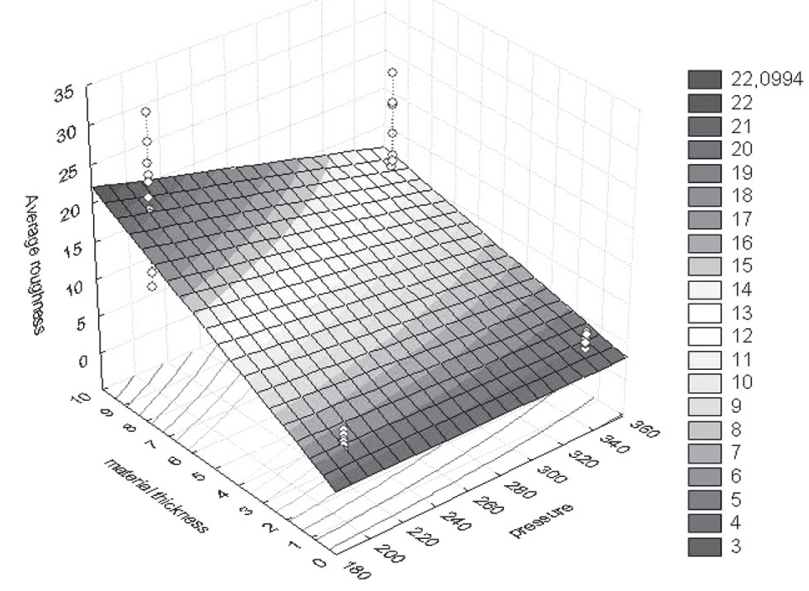

Fig. 12 Fitted surface of material thickness and pressure. Threedimensional surface plot showing predicted average roughness as a function of material thickness [ $\mathrm{mm}]$ and pressure [MPa]

Observations proved influence of selected independent variables on surface roughness. Figures 8, 9, 10, 11 are graphical representation of factors change combination on average roughness measured in three various depths

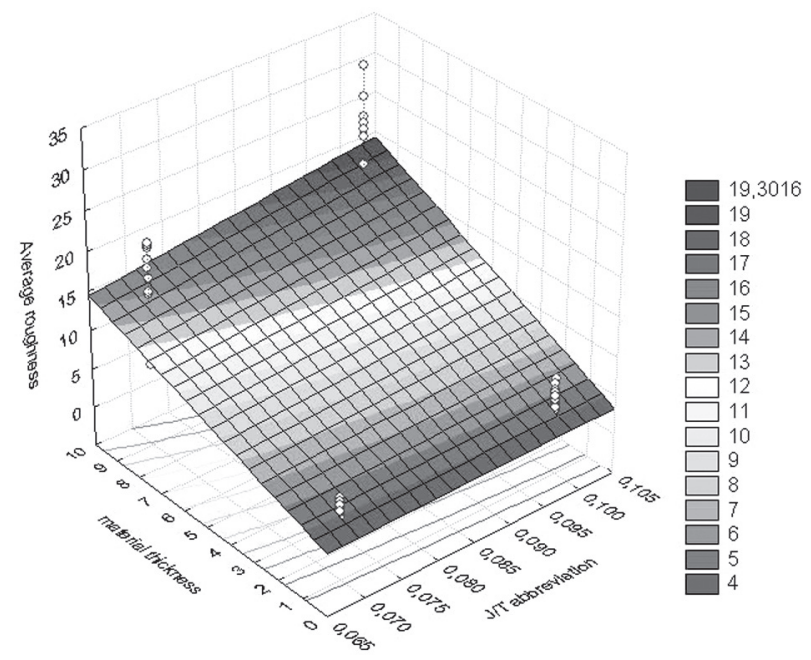

Fig. 13 Fitted surface of material thickness and J/T abbreviation. Three-dimensional surface plot showing predicted average roughness as a function of material thickness [ $\mathrm{mm}]$ and $J / T$ abbreviation [ $\mathrm{mm}$ ]

for samples set A and B where is proven influence of factor $\mathrm{x}_{1}$ (fig. 10). With increasing depth the number values of average roughness increases. The second significant factor is pressure which significantly affects the average roughness (fig. 11). The third significant factor is traverse rate that relates with size and active length of cutting tool. The influence of the traverse rate is shown on the figure 10. As can be seen from graphic interpretations average roughness shows week experimental dependence on change combinations of variable parameters in depth $1 \mathrm{~mm}$. With increasing depth average roughness strongly increases that is caused mainly by factor $\mathrm{x}_{3}, \mathrm{x}_{4}$ (pressure and traverse speed) (fig.8), (fig.9). The roughness significantly increases as the traverse rate increases. The importance of pressure and traverse rate and their significance with interaction material thickness confirm their importance at the cutting of hard machining materials. The impact of $\mathrm{J} / \mathrm{T}$ abbreviation is shown on Figure 12. The important fact is that $\mathrm{J} / \mathrm{T}$ abbreviation with level $-1(0,1 / 1)$ creates more coherent stream. The smaller diameters of diamond orifice and focus tube produce water with higher speed of abrasive water jet. Therefore the surface quality improves with higher pressure and smaller diameter because an abrasive water jet disposes with higher energy concentrated to smaller area of the workpiece. With an increase in the abrasive-mass flow rate, the quality of surface - Ra characteristics improves (fig. 11). But according to planned level conditions that factor there is range of abrasive mass flow rate from 300 g. $\mathrm{min}^{-1}$ to 500 g.min ${ }^{-1}$. From that mentioned reason high abrasive-mass flow rates influence to roughness, is less significant. As the abrasive mass flow rate increases, speed of the abrasive water jet reduces. The main reason is that the higher the mass-flow rate, the higher the number of abrasive particles is that must share the kinetic energy of the water jet. It is assumed that at low values of the factor $\mathrm{x}_{2}$, the particles do not collide one with another. They hit the material with a maximum velocity and maximum possible kinetic energy. The final result is that the abrasive mass flow rate has the less influence as hydrodynamics 
parameters, pressure and $\mathrm{J} / \mathrm{T}$ abbreviation. The increase in the number of impacting particles at lower traverse rates contributes to the improved surface finish.

\section{Conclusion}

The problem analyzed in these pages is the study of abrasive water jet cutting in terms micro cutting quality. The quality parameter average roughness has been measured and evaluated according DoE. This analysis has pointed out that variable independent, pressure; abrasive mass flow rate, pressure, traverse rate and material thickness factor influence the morphology of cutting surface. It has been found that influence of process factors is variable related to different depth. Evaluation has been carried according to design of experiments. Full factorial design has been used as a statistical method to study effects of selected process factors. The pressure, abrasive mass flow rate, traverses rate, $\mathrm{J} / \mathrm{T}$ abbreviation, material thickness, traverse direction as independent variable, has been evaluated their significance and their impact to the average roughness as a dependent variable. Obtained polynomial regression equation after analysis of variance gives the level quality as a function of the process factors. It has been found that pressure, and traverse rate are important with the depth. It has been observed that dominant factors influencing quality are pressure, traverse rate that directly determine quality of the tool - high-speed waterjet connected with thickness material and are most significant at the cutting of hard machining materials. According the experiment it has not been confirmed the significance of traverse direction at the cutting of hard machining materials. A new experiment in the future will be held with consideration of the mesh of solid phase and stand off, as object to reduce of significance absolute member in the model.

\section{References}

[1] Annoni, M., Monno M. A lower limit for the feed rate in AWJ precision machining. In. BHR Group 2000 Jetting Technology, p. 285-295, ISBN 1860582532.

[2] Benko, M., Novák-Marcincin, J. Pocítacová podpora prípravy programov pre rezanie vodným lúcom. In: Automatizácia a pocítacová podpora predvýrobných etáp, výrobných a technologických procesov: 27.-28. marec 2001. Žilina : ŽU, 2001. s. $48-51$.

[3] Hloch, S. - Fabian, S. Abrasive waterjet process factors sensitivity identification. In: Annals of DAAAM for 2005 and proceedings of 16th international DAAAM Symposium, Austria. 1726-9679 : 16, 2005. 159 - 160.

[4] Chen, F.L.; Siores, E. The effect of cutting jet variation on striation formation in abrasive water jet cutting, Industrial Research Institute Swinburne, Swinburne University of Technology, PO Box 218, Melbourne, VIC 3122, Australia, Received 3 March 2000; accepted 10 January 2001, International Journal of Machine Tools \& Manufacture 41 (2001) 1479-1486.

[5] FABIAN, S. - LORKO, M. Some trends of development of measuring instruments and systems. In: Wissenschaftliche Beiträge. no. 6 (2004), p. 12-14. ISSN 0949-8214
[6] FABIAN, S, HLOCH, S. Príspevok k technickým možnostiam zvyšovania kvality produktov technológie vysokorýchlostného hydroabrazívneho prúdu. In: AT\&P journal. 1335-2237 : XII, 2005. 66 - 68. (strany 66 - 68 , 2005),

[7] GOMBÁR M. Tvorba štatistického modelu drsnosti obrobeného povrchu s využitím Matlab. In Výrobné inžinierstvo. (s. 14-17) 2006.

[8] Hashish, M. An Improved Model for Erosion by Solid Particle Impact. In: Proc. Of the 7th International Conference on Erosion by Liquid and Solid Impact, ELSI VII, Cambridge, England, Sept. 1987, 66/1-66/9,

[9] Hashish, M. Machining of Hard Materials with AbrasiveSuspension Jets, Proceedings of the 9th American Waterjet Conference, (Dearbom, Michigan, August 23-26, 1997), pp. 267-280.

[10] Híreš O. The study of cutting surfaces quality. In: Funkcné povrchy 2004: Trencín, 27.-28. máj 2004. Trencín: Trencianska univerzita, 2004. ISBN 80-8075-021-1.

[11] Híreš, O. Povrchové úpravy kovov. Trencín : Trencianska univerzita, ISBN 80-8075-040-8 (viaz.)

[12] Hloch S., Ragan E., Radvanská A.: Application of factorial design to study the effects of the selected abrasive waterjet factors on sound pressure level. In. Proc. Of 4th DAAAM International Conference on Advanced Technologies for Developing Countries, Osijek Croatia, ISBN 3-901509-49-6.

[13] Hloch, S. Fabian, S. Rimár, M.: Design of Experiments Applied on Abrasive Waterjet Factors Sensitivity Identification. In: Nonconventional Technologies Review. 1454-3087 2005. $119-126$

[14] Jurisevic, B., Coray, P. S., Heiniger, K. C., Junkar, M.: Tool Formation Process in Abrasive Water Jet Machining. In: Proceedings of the 6th International Conference on Management of Innovative Technologies MIT'2003 - post-conference edition. Ljubljana: University of Ljubljana. 2003. s. 73-85.

[15] Lebar, A., Junkar, M. Simulation of abrasive water jet cutting process. Modelling Simul. Mater. Sci. Eng. 12 (2004) $1159-1170$

[16] Lupták, M. Study of the measuring and scanning methods in the processes of the cutting and machining with waterjet. In Proc. Metalurgia Junior 05, Den doktorandov HF Košice, 2005.

[17] Palko, A., Smrcek, J., Tuleja, P. Koncové efektory pre roboty 1. In: Strojárstvo. roc. 8, c. 12 (2004), s. 56-57.

[18] Vasilko, K., Kmec, J. Delenie materiálu : Teória a technológia. Presov: DATAPRESS Presov, 2003. 232 s. ISBN 80-7099903-9.

\section{Acknowledment}

The authors would like to acknowledge the support of Scientific Grant Agency of the Ministry of Education of Slovak Republic, Commission of mechanical engineering, metallurgy and material engineering, for their contribution to projects:

- 1/1095/04 - Optimization of abrasive waterjet cutting technology process, by mathematical and experimental planning, (70\%)

- 1/2209/05 Developing method for rising reilability and safety of production systems operation.(30\%) 


\section{Authors}

Assoc. prof., Ing. Stanislav Fabian, PhD.

Faculty of Manufacturing Technologies,

Technical University of Kosice with the seat in Presov,

Department of Technology System Operation,

Štúrova 31, 08001 Prešov, Slovakia

hloch.sergej@fvt.sk

Ing. Sergej Hloch, PhD.

Faculty of Manufacturing Technologies,

Technical University of Kosice with the seat in Presov, Department of Technology System Operation,

Štúrova 31, 08001 Prešov, Slovakia

hloch.sergej@fvt.sk 